\title{
Temporal and spatial fluctuations of phytoplankton in a tropical coastal lagoon, southeast Brazil
}

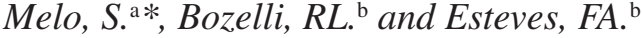 \\ a'Laboratório Plâncton, Instituto Nacional de Pesquisas da Amazônia - INPA/CPBA, \\ Av. André Araújo, 2936, CEP 69060-001, Manaus, AM, Brazil \\ ${ }^{b}$ Instituto de Biologia, CCS, Depto. Ecologia, Lab. Limnologia, Universidade Federal do Rio de Janeiro - UFRJ, \\ Ilha do Fundão, CEP 21940-540, Rio de Janeiro, Brazil \\ *e-mail: melo@inpa.gov.br \\ Received October 13, 2005 - Accepted November 28, 2005 - Distributed August 31, 2007
}

(With 3 figures)

\begin{abstract}
Spatial and temporal variability of the phytoplankton community in the tropical coastal Imboassica lagoon, an environment naturally isolated from the ocean by a narrow sandbar, was analysed every two weeks for 19 months by sampling three sites. During this study, the lagoon received direct input of marine water three times, resulting in remarkable salinity, nutrient concentrations and phytoplankton biomass variations in both temporal and spatial aspects. The phytoplankton biomass presented relatively low values ranging, on average, from $0.54 \mathrm{mg} \cdot \mathrm{L}^{-1}$ in the station closest to the sea (station 1) to $1.34 \mathrm{mg} . \mathrm{L}^{-1}$ in the station close to a macrophyte bank (station 3). Diatoms and cryptomonads dominated in stations 1 and 2 (located relatively close to station 1, yet receiving the runoff of domestic sewage), and euglenoids, cryptomonads and dinoflagellates at station 3. Stations 1 and 2 usually presented the same dominant species but station 2 presented a higher phytoplankton biomass. On the other hand, station 3 showed more similar results concerning phytoplankton biomass with station 2 , however the dominant species were usually different. The high fluctuations of salinity and the reduced nutrient availability are pointed out as the main factors structuring the dynamics of the phytoplankton community at the Imboassica lagoon.
\end{abstract}

Keywords: Diatoms, flagellate algae, coastal lagoon, anthropogenic disturbance, phytoplankton.

\section{Flutuação temporal e espacial do fitoplâncton em uma lagoa costeira tropical do sudeste brasileiro}

\section{Resumo}

Variações espaciais e temporais da comunidade fitoplanctônica da lagoa Imboassica, um ambiente naturalmente isolado do oceano por uma estreita barra de areia, foram analisadas com base em coletas quinzenais, realizadas em três estações, durante 19 meses. Durante este estudo, a barra de areia foi rompida três vezes, resultando em acentuadas variações temporais e espaciais na salinidade, na concentração de nutrientes e na biomassa fitoplanctônica. Esta apresentou valores relativamente baixos, variando de $0,54 \mathrm{mg} \cdot \mathrm{L}^{-1}$ na estação mais próxima ao mar (estação 1) a 1,34 mg. $\mathrm{L}^{-1}$ na estação próxima a um banco de macrófitas (estação 3). Diatomáceas e criptofíceas dominaram nas estações 1 e 2 (esta última localizada, relativamente próxima à estação 1, porém recebendo aporte de esgotos domésticos), e euglenofíceas, criptofíceas e dinofíceas na estação 3. As estações 1 e 2 apresentaram, de modo geral, as mesmas espécies dominantes, diferindo neste aspecto da estação 3 , no entanto, esta diferiu significantemente apenas da estação 1, em termos de biomassa fitoplanctônica. As elevadas flutuações na salinidade e a reduzida disponibilidade de nutrientes são apontadas como os principais fatores estruturadores da dinâmica da comunidade fitoplanctônica na lagoa Imboassica.

Palavras-chave: diatomáceas, algas flageladas, lagoa costeira, distúrbios antropogênicos, fitoplâncton.

\section{Introduction}

Several studies have addressed the importance of pelagic vegetation in freshwater ecosystems, but few studies have been carried out on coastal lagoons. In Brazil, coastal lagoons occur practically throughout the entire coastline, and may be considered to be one of the most representative continental aquatic ecosystems of the country (Esteves, 1998). Cities have developed near or

around many coastal lagoons and on account of this, especially in the state of Rio de Janeiro, they are increasingly threatened with the increasing runoff of effluents that increase eutrophication (Knoppers et al., 1991). Other anthropic disturbances such as landfills and the opening of sandbars also cause strong alterations in the biotic communities and metabolic processes of these 
ecosystems (Faria et al., 1998; Suzuki et al., 1998, 2002; Palma-Silva et al., 2000; Kozlowsky-Suzuki and Bozelli, 2004).

Resource availability, especially of nutrients and light, stands out as the main temporal and spatial factor regulating phytoplankton assemblages. In coastal lagoons, salinity also plays an important role in phytoplankton communities (Rojo and Miracle, 1989; Herrera-Silveira et al., 1998; Domingos and Carmouze, 1993; Torgan et al., 2002). In lagoons isolated from the sea, salinity effects are maximized when the sandbar is open. This favours the development of organisms that are usually more common in brackish and marine environments (Huszar and Silva, 1992; Melo and Suzuki, 1998; Melo et al., 2006).

In the Imboassica Lagoon, the effect of sandbar opening events on phytoplankton and invertebrate communities have been studied by Branco et al. (1998), Melo and Suzuki (1998) and Kozlowsky-Suzuki and Bozelli (2004). However, intensive short term studies of limnological aspects and the phytoplankton communities spanning more than one sandbar opening are still scarce. The investigation reported in this paper looked at the temporal and spatial distribution of the phytoplankton community in the Imboassica Lagoon over a period of nineteen months during which three sandbar opening events occurred.

\section{Material and Methods}

\subsection{Study area}

The Imboassica Lagoon is a small $\left(3.3 \mathrm{~km}^{2}\right)$, shallow (mean depth $1.1 \mathrm{~m}$ ) coastal lagoon located in Macaé $\left(22^{\circ} 24^{\prime} \mathrm{S}\right.$ and $41^{\circ} 42^{\prime} \mathrm{W}$ ) in the northeast of the state of Rio de Janeiro, Brazil (Figure 1). It is separated from the sea by a sandbar that is sometimes opened by man in order to avoid houses from being flooded that were built on the flooding area of the lagoon. The lagoon-sea inlet is kept open anywhere between 15 to 30 days. After this, the sandbar normally closes up rapidly by natural sediment deposition. Another disturbance in the Imboassica
Lagoon is caused by the incoming discharge of domestic sewage. Although the inflow of seawater can be observed during the times that the sandbar is opened, the lagoon is basically supplied with freshwater from a small river and also pluvial waters.

\subsection{Sampling and laboratory analysis}

Integrated samples of the water column were collected at three stations (Figure 1) from November, 1996 to May, 1998. These stations were selected according to their exposure to the inflow of seawater (Station 1), exposure to the inflow of domestic sewage (Station 2), and proximity to an aquatic macrophyte stand made up of Eleocharis mutata (L.) Roem. and Schult. and Typha domingensis Pers (Station 3). Due to the sandbar opening events, it was not always possible to sample at Stations 2 and 3.

Water samples were preserved with a lugol solution for phytoplankton analysis and frozen for nutrient analysis. The water used for the dissolved nutrient analyses was filtered through Whatman GF/F filters immediately upon collecting. The water temperature and salinity were measured in a vertical profile every $0.1 \mathrm{~m}$ with a YSI model 30 hand-held meter (Yellow Springs Instruments). The water transparency was measured with a Secchi disk.

Dissolved oxygen concentrations and $\mathrm{pH}$ were measured about an hour after being collected using the Winkler method (Golterman et al., 1978) and a pH meter (Analion Model PM 608), respectively.

Total phosphorus (TP) and soluble "reactive" phosphorus (SRP) were determined by the molybdenum blue reaction (Golterman et al., 1978). Total nitrogen (TN) and total dissolved nitrogen (TDN) were determined by titration according to the Kjeldahl digestion. Nitrate $\left(\mathrm{N}-\mathrm{NO}_{3}\right)$ was determined by a flow injection analysis using the cadmium reduction method (Mackereth et al., 1978). Ammonium $\left(\mathrm{N}-\mathrm{NH}_{4}^{+}\right)$was estimated by the indophenol colorimetric method (Koroleff, 1976) and dissolved organic nitrogen $(\mathrm{DON})$ was calculated as the difference between TDN and inorganic nitrogen (nitrate and ammo-

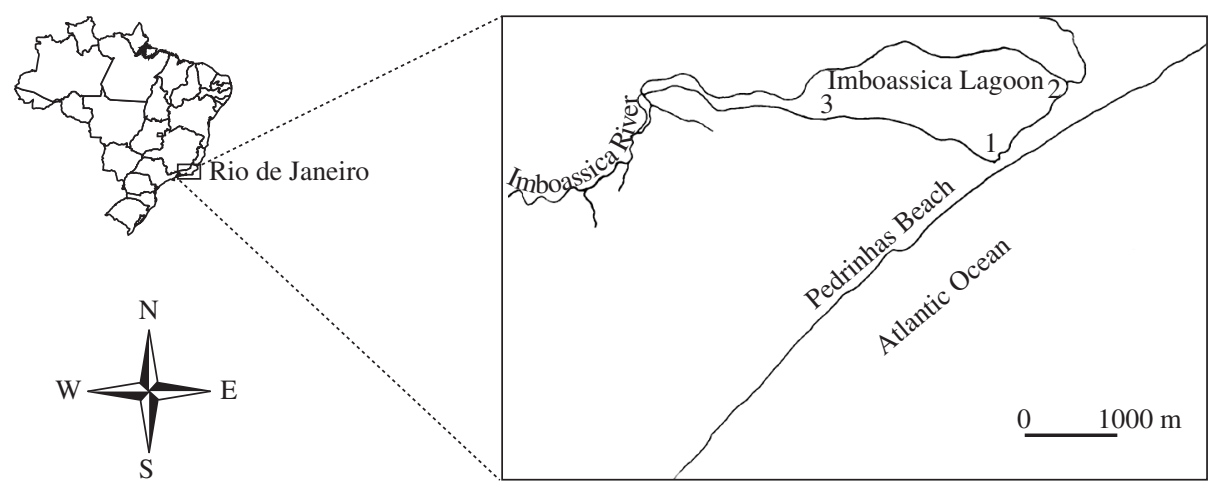

Figure 1. Geographical position of the Imboassica Lagoon. Sampling station indicated by numbers. 
nium). Soluble "reactive" silicon (SRSi) was determined by the molybdate method (Golterman et al., 1978).

The phytoplankton population density was estimated according to Utermöhl (1958) and specific biomass (mg [wet weight] $\mathrm{L}^{-1}$ ) was calculated as the product of population density and mean unit volume (Edler, 1979), assuming a specific cell density of $1 \mathrm{~g} . \mathrm{cm}^{-3}$. The mean diatom unit volume was calculated from the biovolume minus $35 \%$, which corresponds to the vacuoles in pennate forms, and minus $65 \%$, in centric forms (Round et al., 1990). Specific diversity and equitability were calculated by the Shannon-Wiener (Shannon and Weaver, 1963) and Pielou (1966) rates. The species richness is given as the number of taxa per sample.

\subsection{Data analysis}

Taxonomical algal groups were identified according to Hoek et al. (1997). Diatoms were identified according to the classification proposed by Round et al. (1990). In sandbar opening events, phytoplankton composition and biomass variations, six periods were defined to analyse the results (Table 1).

Comparisons of the variables of the different stations were made by the "one way" variance analysis (ANOVA). For the purpose of testing the correlations between the abiotic variables and the phytoplankton (total biomass and the biomass of the main groups), a Spearman correlation was used.

\section{Results}

At the beginning of this study, two sandbar openings occurred in less than two months (November 16, 1996 and January 06, 1997) because of heavy rains and a new one was recorded in February 16, 1998. Salinity increase is one of the major effects brought about by the sandbar opening. In general, higher values of salinity were found at Station 1 which is closest to the sea and lower values were found at Station 3, the lagoon's distal region relative to the sea (Figure 2). The water depth is another sandbar opening effect and this varies from 2.5 to zero meters when the water column was dry. In relation to dissolved oxygen, the lagoon was fairly well oxygenated with decreasing mean values from Stations 3 to 1 (Table 2). With regards to $\mathrm{pH}$, the lagoon was mainly neutral to alkaline. In general, the mean values of nutrients (Table 2) were greater at Station 2, except for soluble reactive silicon and dissolved organic nitrogen that were greater at Station 3 where phytoplankton biomass was also greatest. On the other hand, Station 1 presented greater depth, salinity concentration, $\mathrm{pH}$ and Secchi disk extinction values, but the minor values of phytoplankton biomass had specific diversity and equitability.

The floristic composition of the Imboassica Lagoon (Table 3) was represented by 56 taxa, 39\% of which were diatoms. In general, a fairly low biomass was observed in all stations (Figure 3), but there was a tendency for values to increase from the station nearest the sea towards the most distant station. The Imboassica lagoon was charac-
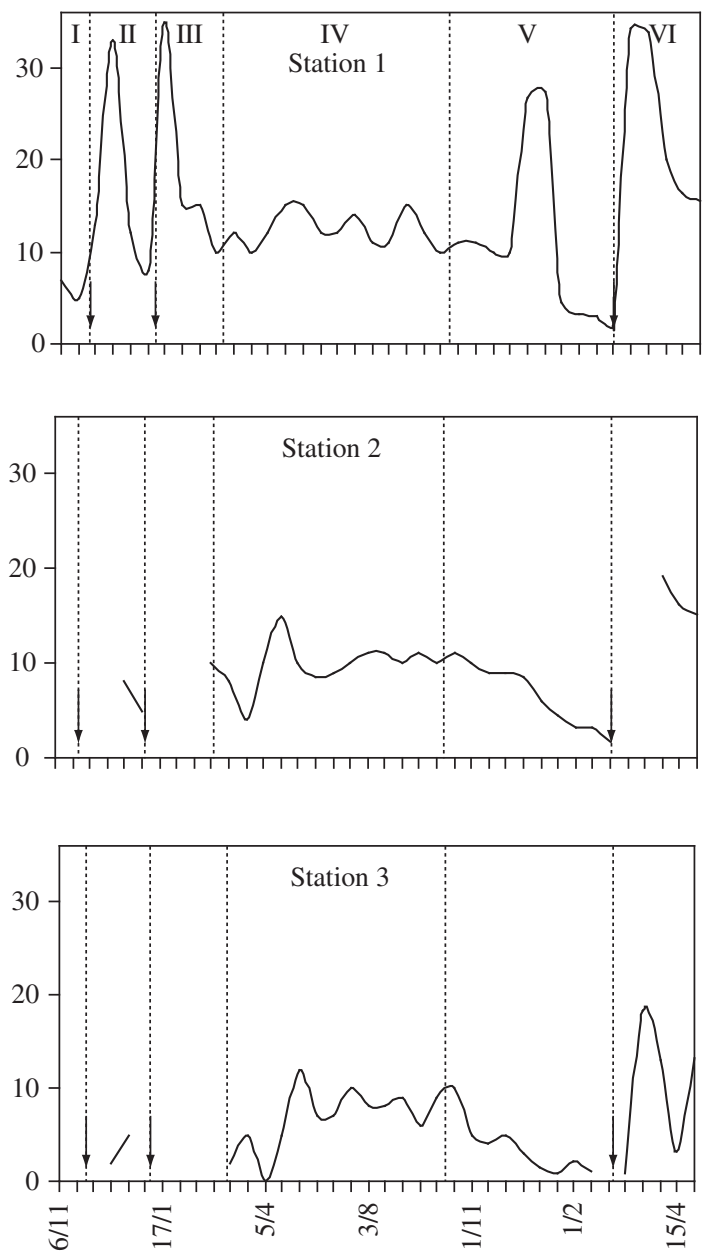

Figure 2. Temporal variations of salinity $(\% \circ)$ in three sample stations in the Imboassica Lagoon from November, 1996 to May, 1998. (The interval between vertical lines show the duration of the periods; the three sandbar openings are shown by arrows).

Table 1. Identification of the six study periods and sandbar openings in the Imboassica Lagoon from November, 1996 to May, 1998.

\begin{tabular}{ccccccc}
\hline & Period I & Period II & Period III & Period IV & Period V & Period VI \\
\hline DP & $06 / 11-11 / 96$ & $21 / 11-27 / 12 / 96$ & $17 / 01-04 / 03 / 97$ & $18 / 03-13 / 09 / 97$ & $03 / 10 / 97-15 / 02 / 98$ & $03 / 03-04 / 05 / 98$ \\
SO & - & $16 / 11 / 1996$ & $09 / 01 / 1997$ & - & $16 / 02 / 1998$ & - \\
\hline
\end{tabular}

$\mathrm{DP}=$ Duration of the periods; $\mathrm{SO}=$ Sandbar opening 
Table 2. Average and standard deviation of abiotic variables and phytoplankton attributes from the Imboassica Lagoon from November, 1996 to May, 1998 in three sampling stations.

\begin{tabular}{lccc}
\hline Abiotic variables/Phytoplankton attributes & Station 1 & Station 2 & Station 3 \\
\hline Temperature $\left({ }^{\circ} \mathrm{C}\right)$ & $25.4 \pm 2.5$ & $25.9 \pm 2.5$ & $26.6 \pm 3.4$ \\
Depth $(\mathrm{m})$ & $1.1 \pm 0.5$ & $0.7 \pm 0.3$ & $0.8 \pm 0.3$ \\
Secchi $(\mathrm{m})$ & $0.9 \pm 0.4$ & $0.6 \pm 0.2$ & $0.7 \pm 0.2$ \\
Salinity $(\%)$ & $14.6 \pm 10.1$ & $9.2 \pm 4.1$ & $6.8 \pm 4.5$ \\
$\mathrm{pH}$ & $8.2 \pm 0.4$ & $7.8 \pm 0.5$ & $7.1 \pm 1.2$ \\
Dissolved oxygen $\left(\mathrm{mg} . \mathrm{L}^{-1}\right)$ & $7.21 \pm 1.27$ & $6.47 \pm 2.26$ & $6.05 \pm 1.8$ \\
Total nitrogen $(\mu \mathrm{M})$ & $35.9 \pm 12.1$ & $53.9 \pm 16.3$ & $51.0 \pm 15.4$ \\
Total phosphorus $(\mu \mathrm{M})$ & $1.0 \pm 0.4$ & $2.4 \pm 1.8$ & $0.8 \pm 0.3$ \\
Dissolved organic nitrogen $(\mu \mathrm{M})$ & $22.5 \pm 7.4$ & $29.4 \pm 9.4$ & $33.2 \pm 11.0$ \\
Dissolved inorganic nitrogen $(\mu \mathrm{M})$ & $5.3 \pm 5.8$ & $23.7 \pm 24.5$ & $12.0 \pm 22.6$ \\
Total dissolved phosphorus $(\mu \mathrm{M})$ & $0.7 \pm 0.3$ & $0.8 \pm 0.6$ & $0.4 \pm 0.2$ \\
Soluble reactive phosphorus $(\mu \mathrm{M})$ & $0.2 \pm 0.1$ & $0.5 \pm 0.5$ & $0.3 \pm 0.1$ \\
Soluble reactive silica $(\mu \mathrm{M})$ & $67.0 \pm 56.0$ & $80.0 \pm 54.0$ & $166.5 \pm 68.0$ \\
Phytoplankton biomass $\left(\mathrm{mg} . \mathrm{L}^{-1}\right)$ & $0.54 \pm 0.58$ & $0.84 \pm 1.0$ & $1.34 \pm 1.7$ \\
Species richness & $12 \pm 3$ & $14 \pm 3$ & $11.0 \pm 4$ \\
Specific diversity (bits.mm $\left.{ }^{-3}\right)$ & $2.1 \pm 0.8$ & $3.0 \pm 0.73$ & $2.40 \pm 1.1$ \\
Equitability $(\%)$ & $60 \pm 19$ & $78 \pm 19$ & $68 \pm 25$ \\
\hline
\end{tabular}

Table 3. Floristic composition of phytoplankton in the Imboassica Lagoon from November, 1996 to May, 1998.

\begin{tabular}{|c|c|}
\hline CYANOPHYTA & CRYPTOPHYTA \\
\hline Anabaena planctonica & Chroomonas nordstedtii \\
\hline Chroococcus microscopicus & Cryptomonas parapyrenoidifera \\
\hline Jaaginema geminata & Cryptomonas pyrenoidifera \\
\hline BACILLARIOPHYTA & Hemiselmis simplex \\
\hline Amphora coffeaeformis & Plagioselmis nannoplanctica \\
\hline Chaetoceros muelleri & Teleaulax acuta \\
\hline Chaetoceros subtilis & DINOPHYTA \\
\hline Chaetoceros wighamii & Durinskia baltica \\
\hline Cocconeis placentula var. euglypta & Gymnodinium sanguineum \\
\hline Craticula halophila & Gymodinium $\mathrm{sp}$ \\
\hline Cyclotella choctawhatcheeana & Prorocentrum aff. cassubicum \\
\hline Cyclotella aff. striata & Prorocentrum minimum \\
\hline Cyclotella pseudostelligera & EUGLENOPHYTA \\
\hline Cylindrotheca closterium & Euglena acus var. acus \\
\hline Eunotia pectinalis & Euglena caudata \\
\hline Gomphonema gracile & Euglena spirogyra \\
\hline Gomphonema parvulum & Eutreptia cf. viridis \\
\hline Mastogloia braunii & Lepocinclis ovum \\
\hline Mastogloia smithii & CHLOROPHYTA \\
\hline Melosira dubia & Chlamydomonas sp. \\
\hline Nitzschia compressa & Closteriopsis acicularis var. acicularis \\
\hline Nitszchia filiformis & Elakatothrix sp. \\
\hline Nitzschia palea & Monoraphidium contortum \\
\hline Nitzschia reversa & Monoraphidium nanum \\
\hline Pleurosigma sp. & Nephroselmis minuta \\
\hline Pseudo-nitzschia sp. & Oocystis submarina \\
\hline RAPHIDOPHYTA & Pseudoscourfieldia marina \\
\hline Chattonella sp. & Pyramimonas grossii \\
\hline PRYMNESIOPHYTA & Resultor mikron \\
\hline Chrysocrhromulina sp. & Scenedesmus grahnensii \\
\hline CRYPTOPHYTA & Tetraedron minimum \\
\hline Campylomonas reflexa & \\
\hline
\end{tabular}



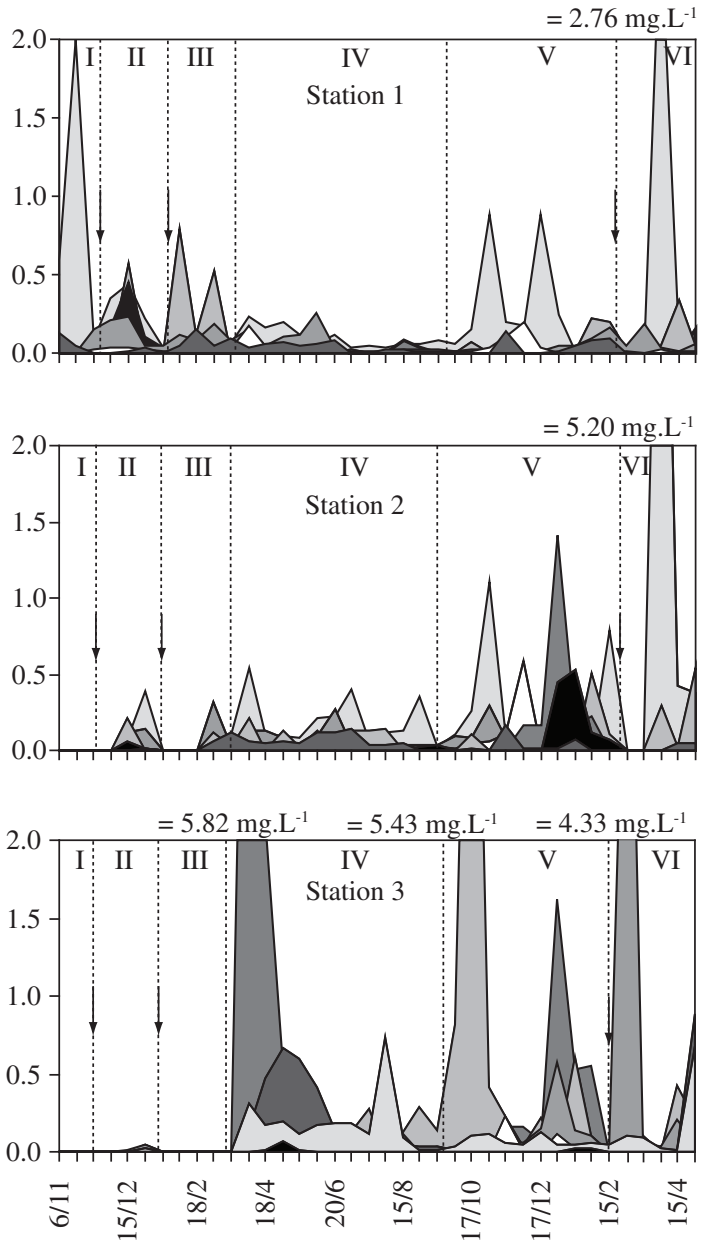

$$
\begin{array}{ll}
\square \text { Euglenophyta } & \square \text { Dinophyta } \quad \square \text { Cryptophyta } \\
\square \text { Chlorophyta } & \square \text { Cyanophyta } \\
\square \text { Bacillariophyta } & \square \text { Heterokontophyta except diatom }
\end{array}
$$

Figure 3. Temporal variations of phytoplankton biomass (mg.L $\left.\mathrm{L}^{-1}\right)$ in three sample stations in the Imboassica Lagoon from November, 1996 to May, 1998. (The interval between the vertical lines show the duration of the periods; the three sandbar openings are shown by arrows).

terized by remarkable temporal biomass variations with values ranging from 0.008 to $6.56 \mathrm{mg} . \mathrm{L}^{-1}$ at station 3 , for instance. On average, phytoplankton biomass fluctuated between 0.54 (station 1) and 1.34 mg.L $\mathrm{L}^{-1}$ (station 3) as shown in Table 2.

At station 1, the highest biomass $\left(2.76 \mathrm{mg} . \mathrm{L}^{-1}\right)$ was observed after the third sandbar opening event (Figure 3). At this time, Pseudo-nitzschia brasiliana Lundholm, Hasle and Fryxell, a recently described species from Brazil (Lundholm et al., 2002) was responsible for $92 \%$ of the total biomass. Nanoplankton organisms $(<20 \mu \mathrm{m})$ were generally dominant at this station (Table 4), and Cyclotella choctawhatcheeana Prasad was the dominant species before the first sandbar opening (November, 1996) with $75 \%$ of the total phytoplankton biomass and, in November and December 1997 when it attained two biomass maximums, 94 and $81 \%$ of the total phytoplankton biomass, respectively (see Melo et al., 2006).

Together with a cryptomonad [Teleaulax acuta (Butcher) Hill] and raphidophytes (Chattonella sp.), C. choctawhatcheeana made up more than $65 \%$ of the biomass in the period between the first and the second sandbar opening events. Immediately following the second and third sandbar openings, dinoflagellates [Prorocentrum minimun (Pavillard) Schiller and Protoperidinium leonii (Pavillard) Balech], cryptomonads (Teleaulax acuta) and diatoms (P. brasiliana) were the most representative groups in terms of biomass.

At station 2, diatoms, cryptomonads, dinoflagellates and blue green algae were the dominant groups (Figure 3). Durinskia baltica (Levander) Carty and Cox, T. acuta and C. choctawhatcheeana made up $63 \%$ of the total biomass prior to the second sandbar opening event (Table 4). No significant variation of phytoplankton biomass was observed from February to September, although there were three small increases in the diatoms Nitszchia filiformis (W. Smith) van Heurck (21\%) and Mastogloia braunii Grunow (19\%) in early April; C. choctawhatcheeana (44\%) in early July; and Melosira dubia Kützing (59\%) and M. braunii (11\%) in early September. However in spring, greater fluctuations were observed. There was an increase in diatom biomass in November with a significant contribution of C. choctawhacheeana (27\%), Melosira dubia (18\%), Nitzschia palea (Kützing) W. Smith (15\%), in addition to Cocconeis placentula Ehrenberg var. euglypta (Ehrenberg) Grunow (10\%). In December, an important increase in Euglena caudata Hübner was recorded when it made up $40 \%$ of the total biomass (12/17) followed by $T$. acuta $(21 \%)$ and D. baltica $(11 \%)$. P. brasiliana was responsible for the biomass maximum in this station (5.20 mg.L $\left.\mathrm{L}^{-1}\right)$ after the third sandbar opening comprising $91 \%$ of the total biomass. After this, M. dubia and Gymnodinium sanguineum Hirasaka were the dominant taxa. In both Stations 1 and 2, another important species was Pyramimonas grossii Parke, especially in November and December of 1997. It made up $48 \%$ of the total biomass in Station 1 in November and reached 64\% of the total biomass in December in Station 2.

At station 3, cryptomonads, dinoflagellates and euglenoids were the dominant groups, especially in the samples just after the sandbar opening (Figure 3). Three very distinct biomass maximums were recorded. The first on April 05, 1997 consisted of euglenoids (Euglena acus Ehrenberg and E. spirogyra Ehrenberg), which represented $83 \%$ of the total biomass $\left(6.58 \mathrm{mg} . \mathrm{L}^{-1}\right)$; the second, on October 17, 1997, when the total biomass was $5.56 \mathrm{mg} . \mathrm{L}^{-1}$ and the dinoflagellates were the dominant group with Prorocentrum cf. cassubicum (Woloszynska) Dodge representing $88 \%$ of the biomass; and the third, when cryptomonads reached a biomass of $4.33 \mathrm{mg} . \mathrm{L}^{-1}$, with Cryptomonas pirenoidifera Geitler and Chroomonas nordstedtii Hansgirg representing 67 and 16\% of the 
Table 4. Main phytoplankton species with more than 5\% of total phytoplankton biomass in the Imboassica Lagoon from three sample stations and in the six periods from November, 1996 to May, 1998. (The number indicates the relative biomass (\%) of each species).

\begin{tabular}{|c|c|c|c|c|c|c|c|c|c|c|c|c|c|c|}
\hline \multirow[t]{2}{*}{ Taxa/Periods } & \multicolumn{6}{|c|}{$\begin{array}{r}\text { Station } 1 \\
\end{array}$} & \multicolumn{4}{|c|}{ Station 2} & \multicolumn{4}{|c|}{ Station 3} \\
\hline & PI & PII & PIII & PIV & PV & PVI & PII & PIV & $\mathbf{P V}$ & PVI & PII & PIV & PV & PVI \\
\hline Chroococcus microscopicus & 9 & - & 10 & 14 & - & - & - & 14 & - & 6 & 7 & 7 & - & - \\
\hline Jaaginema geminata & - & - & - & - & - & - & - & - & - & - & - & 15 & - & 10 \\
\hline Cyclotella choctawhatcheeana & 75 & 24 & 9 & 29 & 43 & - & 19 & 11 & 10 & - & 6 & 10 & - & - \\
\hline C. striata & 12 & - & - & - & - & - & 7 & - & - & 6 & - & - & - & - \\
\hline Melosira nummuloides & - & - & - & - & - & - & - & - & - & 25 & - & - & - & - \\
\hline Nitzschia filiformis & - & 7 & - & - & - & - & - & - & - & - & - & - & - & - \\
\hline N.palea & - & - & - & - & - & - & - & - & - & - & - & - & 7 & - \\
\hline Pleurosigmaa sp. & - & - & - & - & - & - & - & - & 6 & - & - & 7 & - & 7 \\
\hline Pseudo-nitzschia brasiliana & - & - & - & - & - & 19 & - & - & - & 31 & - & - & - & - \\
\hline Chatonella sp. & - & 21 & 8 & - & - & - & 7 & - & 8 & - & - & - & - & 11 \\
\hline Teleaulax aff. acuta & - & 22 & 11 & 10 & 8 & 19 & 22 & 6 & 9 & - & 7 & - & - & - \\
\hline Campylomonas reflexa & - & - & - & - & - & - & - & - & - & - & 9 & - & - & - \\
\hline Chroomonas nordstedtii & - & - & - & - & - & - & - & - & - & - & - & - & - & 13 \\
\hline Cryptomonas pyrenoidifera & - & - & - & - & - & - & - & - & - & - & 41 & - & - & 13 \\
\hline Hemiselmis simples & - & - & - & 6 & - & - & - & - & - & - & - & - & - & - \\
\hline Plagioselmis nanoplanctica & - & - & 7 & 8 & - & - & - & 6 & - & - & - & - & - & - \\
\hline Durinskia baltica & - & - & 6 & - & 6 & - & 22 & - & 8 & 6 & 14 & 10 & 11 & 23 \\
\hline Gymnodinium sanguineum & - & - & - & - & - & - & - & - & 6 & 14 & - & - & - & - \\
\hline Prorocentrum aff. cassubicum & - & - & - & - & - & 12 & - & 8 & - & - & - & 10 & 24 & - \\
\hline P. minimum & - & - & 20 & - & - & - & - & - & - & - & - & - & - & - \\
\hline Protoperidinium leonis & - & - & 10 & - & - & - & - & - & - & - & - & - & - & - \\
\hline Euglena acus & - & - & - & - & - & - & - & - & - & - & - & 6 & - & - \\
\hline E. caudata & - & - & - & - & - & 9 & - & - & 12 & - & - & - & 24 & - \\
\hline E. spirogyra & - & - & - & - & - & - & - & - & - & - & - & 11 & - & - \\
\hline Eutreptia aff. viridis & - & - & - & 6 & - & 7 & - & - & - & - & - & - & - & - \\
\hline Elakatothrix sp. & - & - & - & 6 & - & - & - & - & - & - & - & - & - & - \\
\hline Pyramimonas grossii & - & - & - & - & 8 & - & - & - & 9 & - & - & - & - & - \\
\hline
\end{tabular}

total biomass (4.96 mg.L $\left.\mathrm{L}^{-1}\right)$, respectively on March 3, 1998. Jaaginema geminata (Meneghini ex Gomont) Anagnostidis and Komárek, which represented $46 \%$ of the total biomass on June 5, 1997, and E. caudata that comprised 57 and $58 \%$ of the total biomass on January 6 and February 1, 1998, respectively also stood out in Station 3 (see Table 4).

Significant differences $(p<0.05)$ were found when comparing the average results of the three Stations (Table 5). Station 1 differed from all Stations with the lowest values of total nitrogen, ammonium and phytoplankton biomass. It differed from Station 2 by comparative lower values of total and soluble reactive phosphorus. Moreover, it differed from Station 3 by comparatively higher values of salinity, dissolved oxygen and $\mathrm{pH}$ and by lower values of nitrate and soluble reactive silicon. Finally, Station 2 differed from Station 3 by higher values of salinity, $\mathrm{pH}$, ammonium, nitrate and total phosphorus and by less soluble reactive silicon.

\section{Discussion}

The Imboassica lagoon presented oligohaline to eurihaline water depending on the sandbar openings events and the amount of fresh water discharge. Although only a narrow sandbar makes up the boundary between the lagoon and the ocean, the influence of the ocean with respect to the salinity of the lagoon appears to be more strongly related to the sandbar openings and rough sea events (as occurred in November, 1997) that results in the inflow of salt water. Other salt water incursions such as via sea spray and ground water seepage, assumed by Esteves (1998) as easily found at the Imboassica lagoon, and of recognized influence on the phytoplankton community structure (Rojo and Miracle, 1989), may be pointed out as one of the mechanisms that maintained the higher salinity in Station 1 throughout the study.

Concentrations of soluble reactive phosphorus and dissolved inorganic nitrogen, which are nutrients primarily assimilated by algae, showed great temporal 
Table 5. Comparison by ANOVA of some abiotic variables and phytoplankton biomass from three station samples in the Imboassica Lagoon in the period from November, 1996 to May, 1998.

\begin{tabular}{ccccccccccc}
\hline & Salinity & $\mathbf{p H}$ & $\mathbf{O}_{2}$ & Total-N & $\mathbf{N}_{-} \mathbf{N H}_{4}^{+}$ & $\mathbf{N}-\mathbf{N O}_{3}{ }^{-}$ & Total-P & SRP & $\begin{array}{c}\text { SRSi } \\
\text { Total Phytoplankton } \\
\text { Biomass }\end{array}$ \\
\hline $\mathrm{E} 1-\mathrm{E} 2$ & $\mathrm{~ns}$ & $\mathrm{~ns}$ & $\mathrm{~ns}$ & $* *$ & $* *$ & $\mathrm{~ns}$ & $* *$ & $* *$ & $\mathrm{~ns}$ & $* *$ \\
$\mathrm{E} 1-\mathrm{E} 3$ & $* *$ & $* *$ & $* *$ & $* *$ & $* *$ & $* *$ & $\mathrm{~ns}$ & $\mathrm{~ns}$ & $* *$ & $* *$ \\
$\mathrm{E} 2-\mathrm{E} 3$ & $* *$ & $* *$ & $\mathrm{~ns}$ & $\mathrm{~ns}$ & $* *$ & $* *$ & $* *$ & $\mathrm{~ns}$ & $* *$ & $\mathrm{~ns}$ \\
\hline
\end{tabular}

$* *=$ Significant differences $(\mathrm{p}<0.05)$.

and spatial variation, generally reflecting the influence of sandbar openings and domestic sewage discharge (Melo, 2001). Most of the time, especially at Station 1, they could be considered as limiting to the phytoplankton growth because they were below $0.1 \mu \mathrm{M}$ for soluble reactive phosphorus and $7 \mu \mathrm{M}$ for dissolved inorganic nitrogen, therefore the environment can be considered as chronically deficient for the growth of planktonic algae (Reynolds, 1997). Thus, the lesser biomass at Station 1 might be a consequence of the lesser availability of these nutrients. Limitation by soluble reactive phosphorus in the Imboassica lagoon was found earlier by Panosso and Esteves (1999), who pointed out the hydrolysis of the organic phosphorous by phosphatase activities as the main inorganic phosphorous source to maintain the phytoplankton.

The main limnological parameters (nutrient concentrations, salinity, $\mathrm{pH}$ and temperature) of the Imboassica lagoon are similar according to all sandbar opening events (Melo, 2001). However, there was a difference in the dominance of planktonic algae groups. This was probably due to the presence of inoculum originating from the sediment or from adjacent water bodies at a certain moment. For example, the occurrence and dominance of Pseudo-nitzschia, a primarily marine algae genus, occurred with more than $90 \%$ of the total phytoplankton biomass in Stations 1 and 2, and the high biomass of $P$. cf. cassubicum at Station 3 , a dinoflagellate common in the benthos of brackish environments can be explained by the inoculum input in the water. The occurrence of $P$. brasiliana, for instance, was associated to the presence of it in the neighbouring marine environment in the third sandbar opening, a fact recorded in the same period on the southern seashore of Rio de Janeiro, which highlights the distribution of this genus along the whole Rio de Janeiro state coast (Villac et al., 2005).

The influence of the sandbar opening in the more internal area of the lagoon was reduced when compared to the Station closer to the sea. In the former, there was a prevalence of freshwater, a reduced water column, lower $\mathrm{pH}$ and higher $\mathrm{N}$-amoniacal concentrations. There was also a dominance of euglenoids (E. acus and E. spirogyra) and cryptomonads (C. pyrenoidifera, $C$. parapyrenoidifera and $C$. nordstedtii) after the second and third sandbar opening events, respectively, when the freshwater inflow still predominated at this station. In addition to the oligohaline conditions, the input of organic matter coming from the decomposing macrophytes may have been another factor that affected the development of these algae (Klaveness, 1988; Reynolds et al., 2002).

The higher biomass of Station 2 compared to Station 1 can probably be explained by the higher availability of nutrients originating from the sewage discharge and to the greater plant organic matter in that area, as registered by (Lopes-Ferreira and Pasin, 1998; Palma-Silva, 1999). In the station further from the sea (Station 3 ) the dominant species was characteristic of both freshwater and mesohaline environments. Although, in general, nutrient concentrations at Station 3 were lower than at Station 2, the phytoplankton biomass did not differ significantly, but the dominant species did. At station 3 , the maximum biomass values are attributed to the expressive development of euglenoids and cryptomonads after the second and third openings of the sandbar and by $P$. cf. cassubicum in Period V. On the other hand, the high biomass values at Station 2 are attributed to $P$. brasiliana in Period VI.

The sandbar opening events were followed by a temporary dominance of species common to marine and brackish environments, such as the dinoflagellates P. leonis and P. minimum and the diatom P. brasiliana at Stations closer to the sea. As has been recorded for zooplankton, (Kozlowsky-Suzuki and Bozelli (2004), large marine algae enter the lagoon bringing about an increase in the phytoplankton biomass. On the other hand, the frequent sandbar opening events recorded in this study contributed to the nutrient export from the lagoon which prevented an increase in eutrophication. This influence of sandbar opening events on a trophic level was emphasized by Melo et al. (2003) who registered hypereutrophic conditions in the Imboassica lagoon after a period of two years without sandbar openings.

To conclude, three distinct areas were identified in the lagoon according to their salinity, $\mathrm{pH}$, dissolved oxygen, nutrient and phytoplankton biomass. Salinity and nutrient concentrations may be confirmed as the factors that most influenced the spatial distribution of the phytoplankton in the Imboassica lagoon. Taking the species that most contributed in terms of biomass at the three stations, it can be observed that a greater similarity was found between stations closer to the sea, as compared to the more distant ones. Similar salinity at Stations 1 and 2 suggest that this is probably the main selective factor for the similar dominant species at these stations, especially 
C. chctawhatcheeana, P. brasiliana, P. nanoplanctonica and T. acuta.

Acknowledgments - The authors are indebted to the valuable criticisms and suggestions put forward by Vera L. M. Huszar, Lúcia Helena Sampaio da Silva and also the taxonomical help of Mariângela Menezes, Lezilda Torgan and Maria Célia Villac; and Barbara Ann Robertson for revising the English. This work was funded by PETROBRAS, PRONEX-MCT, FAPERJ, CAPES and CNPq.

\section{References}

BRANCO, CWC, ATTAYDE, JL. and KOZLOWSKY-SUZUKI, B., 1998. Zooplankton community of a coastal lagoon subjected to anthropogenic influences (Lagoa Imboassica, Macaé, R.J. Brazil). Verh. Internat. Verein. Limnol. vol. 26, p. 1426-1429.

DOMINGOS, P., and CARMOUZE, JP., 1993. Influences des intrusions de masses d'air polaires sur le phytoplancton et le métabolisme d'une lagune tropicale. Rev. Hydrobiol. Trop. vol. 26 , no. 4 , p. 257-267.

EDLER, L., 1979. Recommendations for marine biological studies in the Baltic Sea. Phytoplankton and chlorophyll. Unesco, Working Group 11, Baltic Marine Biologists, National Swedish Environmental Protection Board, Stockholm. 38p.

ESTEVES, FA., 1998. Lagoas costeiras: Origem, funcionamento e possibilidades de manejo. In Esteves, FA. (ed.). Ecologia das lagoas costeiras do Parque Nacional da Restinga de Jurubatiba e do Município de Macaé (RJ). NUPEM-UFRJ, Macaé, Rio de Janeiro. p.63-87.

FARIA, BM., SUZUKI, MS. and PRAST, AE., 1998. Changes in the metabolism of a Brazilian lagoon related to man-made marine entrances. Verh. Internat. Verein. Limnol. vol. 26, p. $1442-1444$.

GOLTERMAN, HL., CLYMO, RS. and OHNSTAD, MAM., 1978. Methods for Physical and Chemical Analysis of Freshwaters. I.B.P. Handbook, Blackwell Scientific Publications, Oxford. no. 8, 213p.

HERRERA-SILVEIRA, JA., RAMÍREZ-RAMÍREZ, J. and ZALDIVAR, AJ., 1998. Overview and characterization of the hydrology and primary producer communities of selected coastal lagoons of Yucatán, México. Aquatic ecosystem health and managemen. vol. 1, p. 353-372.

HOEK, C., MANN, DG. and JAHNS, HM., 1997. Algae: an introduction to phycology. Cambridge University Press, Cambridge, 627p.

HUSZAR, VLM. and SILVA, LHS., 1992. Comunidades fitoplanctônicas de quatro lagoas costeiras do norte do Estado do Rio de Janeiro, Brasil. Acta Limnol. Brasil. vol. 4, p. 291-314.

KLAVENESS, D., 1988. Ecology of the cryptomonadida: a first review. In Sandgreen, C. D. (ed) Growth and Survival Strategies of Freshwater Phytoplankton. Cambridge University Press, Cambridge, p. 105-133.

KNOPPERS, B., KJERFVE, B. and CARMOUZE, JP., 1991. Tropic state and water turn-over time in six choked coastal lagoons in Brazil. Biogeochemistry. vol. 14, p. 149-166.

KOROLEFF, F., 1976. Determination of phosphorus. In: Grasshoff, K.. (ed.). Methods of seawater analysis. Verlag Chemie, Weinheim/New York. p. 117-126.
KOZLOWSKY-SUZUKI, B. and BOZELLI, RL., 2004. Resilience of a zooplankton community subjected to marine intrusion in a tropical coastal lagoon. Hydrobiologia. vol. 522, p. $165-177$.

LOPES-FERREIRA, C. and PASIN, EB., 1998. Distribution of total nitrogen and phosphorus concentrations at sewer outfall at Imboassica Lagoon, RJ, Brazil. Verh. Int. Ver. Limnol., vol. 26, p. 1491-1493.

LUNDHOLM, N., HASLE, GR., FRYXELL, GA. and HARGRAVES, PE., 2002. Morphology, phylogeny and taxonomy of species within the Pseudo-nitzschia americana complex (Bacillariophyceae) with descriptions of two new species, Pseudo-nitzschia brasiliana and Pseudo-nitzschia linea. Phycologia. vol. 41, p. 480-497.

MACKERETH, FJ., HERON, H.J. and TALLING, JF., 1978. Water analysis: some revised methods for limnologists. Freshwater Biological Association Scientific Publication no. 36. Ambleside. 120p.

MELO, S., 2001. Fitoplâncton da lagoa Imboassica (Macaé, RJ-Brasil): flora, estrutura de comunidade e variações espaciais e temporais. Ph.D. Thesis, Universidade Federal do Rio de Janeiro, Rio de Janeiro, 163p.

MELO, S. and SUZUKI, MS., 1998. Variações temporais e espaciais do fitoplâncton das lagoas Imboassica, Cabiúnas e Comprida. In: Esteves, FA. (ed.). Ecologia das lagoas costeiras do Parque Nacional da Restinga de Jurubatiba e do Município de Macaé (RJ). NUPEM-UFRJ, Macaé, Rio de Janeiro. p. $177-203$

MELO, S., TORGAN, LC., MENEZES, M., HUSZAR, VLM., CORRÊA Jr JD. and BOZELLI. RL., 2003. Taxonomy and ecology of Synedropsis roundii sp. nov. (Bacillariophyta) from a tropical brackish coastal lagoon, south-eastern Brazil. Phycologia. vol. 42, no. 1, p. 71-79.

MELO, S., TORGAN, LC., MENEZES, M. and CORRÊA JR. JD., 2006. First report of Cyclotella choctawhatcheeana (Bacillariophyta) from Brazilian tropical waters: ultrastructure and ecology. In: Witkowski, A. (ed.). Eighteenth International Diatom Symposium 2004. Biopress Limited, Bristol. p. 293-299.

PALMA-SILVA, C., 1999. Ecologia de macrófitas aquáticas em uma lagoa costeira sujeita a impactos antrópicos (Lagoa Imboassica, Macaé, RJ). (Ph.D. Thesis) - Universidade Federal do Rio de Janeiro, Rio de Janeiro, 153p.

PALMA-SILVA, C., ALBERTONI, EF. and ESTEVES, FA., 2000. Eleocharis mutata (L.) Roem. et Schult. subject to drawdowns in a tropical coastal lagoon, State of Rio de Janeiro, Brazil. Plant Ecology, vol. 148, p. 157-164.

PANOSSO RF. and ESTEVES, FA., 1999. Phosphatase activity and plankton dynamics in two tropical coastal lagoons. Archiv Hydrobiol. vol. 146, p.341-354.

PIELOU, EC, 1966. The measurement of diversity in diferent types of biological collections. J. Theoret. Biol. vol. 13, p. 131-144.

REYNOLDS, CS., 1997. Vegetation processes in the pelagic: A model for ecosystem theory. Excellence in ecology, Ecology Institute, Germany. vol. 9, 371p.

REYNOLDS CS., HUSZAR V., KRUK C., NASELLI-FLORES L. and MELO S., 2002. Towards a functional classification of the freshwater phytoplankton. J. Plankton Res. vol. 24, p. 417-428. 
ROJO, C. and MIRACLE, MR., 1989. Phytoplankton fluctuations during an annual cycle in the coastal lagoon of Cullera (Spain). Int. Revue ges. Hydrobiol. vol. 74, no. 2, p. 179-194.

ROUND FE., CRAWFORD, RM. and MANN, DG., 1990. The diatoms. Biology and morphology of genera. Cambridge University Press, Cambridge. 747p.

SHANNON, CE. and WEAVER, W. 1963. The mathematical theory of communication, Urbana, Illinois University Press. $177 \mathrm{p}$.

SUZUKI, MS., OVALLE, ARC. and PEREIRA, EA., 1998. Effects of sand bar openings on some limnological variables in a hypertrophic tropical coastal lagoon of Brazil. Hydrobiologia vol. 368, p.111-122.

SUZUKI, MS., FIGUEIREDO, RO. CASTRO, SC. SILVA, CF. PEREIRA, EA. SILVA, JA. and ARAGON, GT., 2002. Sand bar opening in a coastal lagoon (Iquipari) in the northern region of Rio de Janeiro State: Hydrological and Hydrochemical changes. Braz. J. Biol., vol. 62, no. 1, p. 51-62.

TORGAN, LC., TUNDISI, JG. and NIENCHESKI, LFH., 2002. Seasonal variation of planktonic diatoms during an annual cycle in Patos Lagoon, Southern Brazil. In Proceedings of the 15 th International Diatom Symposium, Perth, Australia. Published by A. R. G. Gantner Velag K. G., Ruggell/Liechtenstein. p. $459-470$.

UTERMÖHL, H., 1958. Zur Vervollkomnung der quantitativen Phytoplankton-Methodik. Mitt. int. Ver. Limnol., vol. 9, p. 1-38.

VILLAC, MC., MELO, S., MENEZES, M. and TENENBAUM, DR., 2005. Pseudo-nitzschia brasiliana (Bacillariophyceae), an opportunistic diatom on the coast of the state of Rio de Janeiro, Brazil. Atlantica. vol. 27, no. 2, p. 139-145. 
